\title{
Violence in intimate relationships from the point of view of adolescents: perspectives of the Complexity Paradigm****
}

\author{
A violência na relação de intimidade sob a ótica de adolescentes: \\ perspectivas do Paradigma da Complexidade \\ La violencia en la relación de intimidad bajo la óptica de los \\ adolescentes: perspectivas del Paradigma de La Complejidad
}

How to cite this article:

Campeiz AB, Carlos DM, Campeiz AF, Silva JL, Freitas LA, Ferriani MGC. Violence in intimate relationships from the point of view of adolescents: perspectives of the Complexity Paradigm. Rev Esc Enferm USP. 2020;54:e03575. doi: https://doi.org/10.1590/S1980-220X2018029003575

\section{Ana Beatriz Campeiz ${ }^{1}$ \\ Diene Monique Carlos ${ }^{2}$ \\ Ana Flávia Campeiz ${ }^{1}$ \\ Jorge Luiz da Silva ${ }^{3}$ \\ Luiza Araújo Freitas ${ }^{1}$ \\ Maria das Graças Carvalho Ferriani $^{1}$}

* Extracted from the dissertation: "A violência nas relações de intimidade entre os adolescentes sob a perspectiva do Paradigma da Complexidade", Escola de Enfermagem de Ribeirão Preto, Universidade de São Paulo, 2018.

** Invited authors, CIAIQ 2017

${ }^{1}$ Universidade de São Paulo, Escola de Enfermagem de Ribeiro Preto, Departamento de Enfermagem Materno-infantil e Saúde Pública, Ribeirão Preto, SP, Brazil.

${ }^{2}$ Universidade Federal de São Carlos,

Departamento de Enfermagem,

São Carlos, SP, Brazil

${ }^{3}$ Universidade de Franca, Departamento de Saúde Pública, Franca, SP, Brazil.

\begin{abstract}
Objective: To analyze adolescents' perceptions about intimate violence from the perspective of the Complexity Paradigm. Method: A qualitative approach configured as strategic social study. The study participants were adolescents between 15 and 18 years old, attending high school in two public schools in a city in the interior of São Paulo State, Brazil. Data collection was performed through a focus group and a semi-structured interview as a complement. Data analysis was based on the dialogical, organizational and holographic principles of the Complex Paradigm. Results: The study included 39 adolescents (14 males and 25 females). Through the emerging categories, it was noticed that intimate violence occurs through dialogical affection-jealousy/control by a naturalization of violent acts which permeates gender, cultural and social issues, and by technology as preponderant for intimate violence among adolescents, denoting new forms of control and coercion. Conclusion: The study introduces aspects present in intimate violence among adolescents, presenting them in an articulate and interdependent way. These aspects constitute a relevant contribution to the actions of health professionals.
\end{abstract}

\section{DESCRIPTORS}

Adolescent; Intimate Partner Violence; Student Health; Qualitative Research.
Corresponding author:

Ana Beatriz Campeiz

Av. dos Bandeirantes, 3900, Campus

Universitário, Monte Alegre

CEP 14040-902 - Ribeirão Preto, SP, Brazil

biacampeiz@hotmail.com
Received: 08/02/2018

Approved: 08/29/2019 


\section{INTRODUCTION}

Intimate Partner Violence (IPV) in contemporary times, especially among adolescents, has been occurring steadily. The World Health Organization classifies adolescence as the phase corresponding to the age group between 10 and 19 years, which is a period of biopsychosocial changes in which there is greater exploration of experiences and desire for a sense of autonomy, as well as searches and experiences which provide greater exposure to risky/vulnerable situations and practices, as well as violence ${ }^{(1)}$. Among these practices is the involvement in abusive intimate relationships, mainly resulting from the beginning of sexual relations and belief in romantic love. Gender identity construction and generation subordination can be associated with considerable vulnerability to an experience of victimization or perpetration of IPV among adolescent partners ${ }^{(2)}$.

In addition, adolescents' inability to respond to violence makes them more susceptible to short- and long-term physical, psychological and emotional harm compared to adulthood $^{(3-6)}$. Given this, the moment of adolescence requires a particular look and policies ${ }^{(1)}$.

IPV may be characterized as physical, verbal, sexual or psychological/emotional, and may arise from a close or personal relationship between two individuals. One of the forms of violence which is most manifested in intimate relationships between adolescents is known as Stalking, a notion which refers to the act of following, threatening and controlling the other individual, generating emotional states of fear and insecurity. The IPV manifestation may be punctual or continuous, unidirectional or bidirectional, and is not limited to sexual orientations, but may occur between homosexual and heterosexual subjects ${ }^{(7)}$.

National and international literature reveals worrying rates of IPV among adolescents. In addition to the serious consequences, a longitudinal study emphasizes normalization and legitimation of abusive behaviors in IPV by adolescents ${ }^{(8)}$. An interpretation of the phenomenon as being normal was also revealed in a recent study ${ }^{(3)}$, in which adolescents who had suffered some form of IPV did not feel it to be constituted as such, nor did they act with any difference in interpreting it. Thus, IPV victims in adolescence tend to consent to, exhibit and repeat the same patterns of violent attitudes, and allow certain behaviors in the context of other relationships ${ }^{(4,9)}$.

Part of this study was presented at the VI IberoAmerican Congress of Qualitative Research in 2017, exploring the different dimensions of violence which materialize in intimate relationships. This research aimed to analyze the perceptions of adolescents about violence in intimate relationships. For this, the epistemological position is based on the Complexity Paradigm ${ }^{(10)}$, which denies opposition between complexity and simplicity, and understands what is "woven together" as complex and is, in fact, the fabric of actions, chance, events, determinations, interactions and feedback which form our phenomenal world ${ }^{(11-12)}$. Thus, when considering contradictions and unpredictability ${ }^{(12)}$, Complex Thinking enables a multidimensional view and understands the violence phenomenon within intimate relationships in the interaction and interdependence of its elements and in context, enabling a broader look and a greater degree of understanding and knowledge.

The originality of the present study is emphasized, since there are no articles found in the literature which consider IVP from the perspective of the Complex Paradigm, as well as a lack of qualitative approaches and the need for studies with more contextualized perspectives. Added to this is the importance of looking at this phenomenon through health, especially nursing's perspective, which needs to include contemporary issues permeating the lives of adolescents in its agenda, necessarily involving themselves in their health-disease process.

\section{METHOD}

\section{Studi Design}

This study implemented a qualitative approach using strategic social research based on the dialogical, organizational and holographic recursion principles of Complex Thinking, which were used as support to obtain and analyze the data.

The dialogical principle, when presenting organization and complexity, claims the conjugation of two complementary and antagonistic logics at the same time ${ }^{(11-12)}$. The organizational recursion principle enables interconnection which gives characteristics to the phenomenon, negates the linear cause/effect relationship and reveals the individual as a product and producer of their interactional processes $^{(10,12)}$. Finally, there is the holographic principle, which looks at the whole and at the same time it embraces and allows for separation between the parts, without losing their specificities $^{(11-12)}$.

\section{SCENARIO}

The field of study was a municipality in the interior of the state of São Paulo, Brazil, which has a population of 61,040 inhabitants ${ }^{(13)}$. The study included 39 adolescents (14 males and 25 females) aged 15 to 18 , attending high school in two public schools. Participants were from three $2^{\text {nd }} y e a r$ classes and one $3^{\text {rd }}$ year high school class. The schools were chosen randomly and the preference for the $2^{\text {nd }}$ and $3^{\text {rd }}$ year was proposed by the school boards to enable better internal organization.

\section{SeleCtION CRITERIA}

The selection criteria for the participants were: i) To be attending the first to third year of high school, both genders and of any sexual orientation; ii) Delivering the Free and Informed Assent Form for adolescents under 18 years of age, and the Free and Informed Consent Form (ICF) of the adolescents' guardians completely filled in and signed; and iii) Full participation in a focus group (FG).

\section{Data collection}

Focus groups and semi-structured interviews were performed to obtain the data. A FG occurs through dialogue 
and interaction between a group of individuals, assimilating similar and different visions and shared experiences ${ }^{(14)}$. Thus, the participating adolescents were randomly divided and formed into four groups to perform the FGs. Each group held two meetings, ranging from seven to ten participants and between 40 and 60 minutes each session. A pre-established script guided the debate at the first meeting of the FGs, which sought to learn: i) What constitutes an intimate relationship and how should it be ideally? ii) What are the positive and harmful behaviors in an intimate relationship? iii) What is considered violence and if IPV could exist; and iv) What are the forms of violence and their causes within an intimate relationship in the participants' perspective? Printed images were presented representing couples embracing and arguing in order to stimulate this discussion, as well as messages of love, among other triggering figures.

Another pre-established script guided the debate in the second meeting through affirmative phrases such as: i) Alcohol or drugs are responsible for the violence of people, so whoever uses them is not guilty of being violent; ii) Swearing or squeezing the arm of the boyfriend/girlfriend during an argument is no problem, because they were "hot-headed"; iii) People who are mistreated and do not ask for help is something which occurs because they do not care about the situation, among others. As participants identified with their beliefs, they manifested themselves through a model established as: 1 - I do not agree; 2 - I agree little (maybe); 3 - I agree; and 4-I strongly agree. Thus, they were encouraged to explain their beliefs and convictions about violence and adolescent intimate relationships.

Semi-structured interviews promote an intersubjective relationship between the interviewer and the interviewee, better enabling the particular meanings and specific experiences of each participant. Thus, 15 interviews were conducted lasting from 20 to 35 minutes, with six male and nine female participants. Open and guiding questions were used, enabling the researchers to identify what it would be like to be in an intimate relationship, if there could be (and how) IPV occurs, and if they had experienced any situation of violence.

Situations which occurred in the participants' actions during the performance of the FGs which caught the researcher's attention, such as demonstrating discomfort due to a question asked or another participant's speech, in addition to giving up speaking up or not completing a report were one of the criteria used to choose the 15 interviewees. The other would be participation in FG and demonstrating free interest.

After defining the school and the participants based on the availability and organization of the school unit, data collection was performed from October 2016 to April 2017. Participants were assigned in the order of the FG (G1, G2 and following) and interviews (I1, I2 ...), and were identified with the letter $\mathrm{P}$ and numbered according to the sequence in which the speeches were made: $\mathrm{P} 1, \mathrm{P} 2$, and so on, in order to keep their identity confidential. The letters $M$ and $W$ were used in both strategies to designate the reports of men and women, respectively.
The data obtained in the researchers' evaluation showed redundancy and repetition after the $4^{\text {th }} \mathrm{FG}$ and $15^{\text {th }}$ interview; thus, the inclusion of new participants in the strategies was finalized. The researchers followed a script which takes into account the empirical limits of the data, the integration of the data with the theory, and the theoretical sensitivity of the researchers analyzing the data for saturation reliability ${ }^{(15)}$.

The researcher performed a member-check at the end of the FGs and semi-structured interviews, which means they consulted the participants again to see if their findings reproduced what the adolescents actually said, felt and thought about IPV. The teens listened to their recorded reports and were able to confirm their perceptions or rephrase some statement(s) when they thought they had expressed themselves badly or were not clear enough.

\section{DATA ANALYSIS AND PROCESSING}

An analysis of the obtained data was based on the Complexity Paradigm and a script with three phases was performed $^{(16)}$ : i) Classification and organization of the collected information, determining the relevant points of the interviews and FGs, concomitantly providing a total view of the data, phenomenon and its particularities. The reports were transcribed in full and with the identification of each participant; (ii) Organization of frames of reference and consequently the categories; iii) Establishment of relationships between the data found by organizing them into categories, existing scientific literature on IPV among adolescents and the Complexity Paradigm. The data analysis and processing were based on the notion of contextualization constituting the proposed Paradigm and on the elucidation of some participants' reports. This aimed at achieving the research objective and being authentic to the participants' interpretations so as to accomplish credibility and validity in the data analysis.

\section{ETHICAL ASPECTS}

The study was approved by the Research Ethics Committee of the Universidade de São Paulo at Ribeirão Preto College of Nursing through Official Letter No. 279/2016, on August 31, 2016, according to Resolution no. 466/12 of the National Health Council on research with human beings. Accordingly, spontaneous consent was requested by signing the Informed Consent Form (ICF). In order to carry out the study, the approval of the Education Board of the Region and the participating school units was requested.

\section{RESULTS}

\section{Characterization}

The students attending the third year of high school were contacted in one of the schools which constituted the research sites, designated as $\mathrm{S} 1$, and totaled 17 . This low number of students is justified by the fact that there was only one class in the school at full time. In the other school, designated as S2, there were three classes in the second year 
of high school, which had 28, 31 and 32 students. The teenagers at this school participated in the FGs at the end of the 2016 school year while attending the end of the second year of high school, and the semi-structured interviews at the beginning of the 2017 school year, when they were already in their third year.

Given the inclusion criteria, 39 adolescents participated in the study. The participants were: 7 from the S1 school (18\%) and 32 from the S2 school (82\%). In the S1 and S2 schools, $28.5 \%$ and $37.5 \%$ of participants were male, while $71.5 \%$ and $62.5 \%$ of participants were female, respectively. At the time of the survey, two female participants from the $\mathrm{S} 1$ and three female participants from the S2 (two female and one male) reported not having experienced any intimate relationships.

\section{"IIT'S NORMAL", "IT'S ACCEPTABLE" AND "IT hapPENS"}

Feelings and reactions involving passivity towards IPV were characterized as accepted and common by adolescents: I think it's normal, you're on edge. It happens. Sometimes squeezing the arm, grabbing the neck (P4/M-G3).

Emotional blackmail, it's bullshit for a woman to fall for it (P4/M-G1).

The reports also highlighted issues related to gender and passivity towards violence perpetrated by women, denoting a taboo still existing in society and the reproduction of stigmatizing issues:

I think when a man is violent, he can swear, but not hit. The difference is in the force. If we punch bim, he'll feel it softly, now if he punches, we'll get bruised (P5/W-G3).

Woman do something lighter, if their nails are long she scratches, uses her nails [laughs], pinches, tries to pull hair, when the guy has it [laughs]. But like, the man is stronger (I13/M).

The possibility of the man being the victim rather than the perpetrator of violence in the relationship was lower. In addition, there was an association of violence against women with the Maria da Penha Law as a form of unilateral punishment. These ideas were explicitly presented in many accounts similar to the following transcripts:

Before there were no women beating a man, it's difficult, and if there is now, it is infrequent (P8W-G3).

Women get beaten much more than men. But when the man is beaten, the man never goes after his rights, because nowadays he doesn't have the "José da Penha" law, he can go to jail, so women take advantage of it. A man doesn't ask for help out of shame (I11/M).

A lack of understanding by participants of the sexual coercion/violence manifested in forced kissing was evidenced. This perception was reflected in the following reports: I don't think this [forced mouth kiss] is violence. We're dating, you know he'll always be wanting to kiss you, whether you want to or not. If you don't want to, even in a fight, then you can quit. Because even I'm angry, sad, and I don't kiss, he will think that I'm with another guy. And I'll think the same of him (P7/W-G2).

If someone tries to kiss me forcibly, you know, if it's a stranger, it's violence, right. But not by a boyfriend, he's my boyfriend right? (P9/W-G3).

The existence of a relationship implied giving in to her boyfriend's wishes. Therefore, the adolescent's emotional states no longer determine their own desire: denying a kiss would indicate a possible betrayal on one side or the other. From another perspective, giving in to a stranger's kissing was considered violence, but letting your boyfriend was not. For the participants, even if the partner did not respect their partner's limits or wishes, the ideal would be to have consent, as if it were a clause written in an invisible contract which strived for accepting a forced kiss. Thus, this form of sexual coercion was relativized as a pact in which violence is considered external to the relationship.

\section{"VIOLENCE: ITS DIMENSIONS AND EXPERIENCES"}

When the other, the partner, was the perpetrator of the violence, it was interpreted as a manifestation of love, thus denoting a syncretism of love and violence, as one sees in the following statements:

If I was going out I had to take her wherever I went (...). She was very loving, suffocating (...) (E2/M).

But he doesn't want to control, he wants to prevent his girlfriend from having something happening, to avoid a fight or anything. This is love (P1/W-G1).

Several forms of physical, sexual, verbal and psychological violence were reported:

At the beginning of the relationship he controlled my clothes, where I went, who I talked to, I had this problem a lot, but then I complained, and he stopped ... But I don't have male friends, he wouldn't accept that (P5/W-G1).

She scratches me a lot ... but I do nothing, never did anything. Sometimes I swear, curse, but I don't touch her, but look at my back, my arms, I'm all scratched (E4/M).

She kept calling me fat ... asshole ... such things ... because she was ashamed, and she kept making fun of me (E8-M).

When the participant was the perpetrator of violence, control and jealousy gained prominence as a justification for such acts:

I'm already possessive psychotic jealous, I have that kind of problem. The person has to accept as I am, this is love right ( $\mathrm{P} 1 / \mathrm{W}-$ -G1).

Ah like, in the case of another man I say: 'What are you looking at, she's mine (P1/M-G3).

This reveals expressing jealousy as a manifestation of love and not of violence by adolescents. In this context, many forms of violence end up being veiled, such as psychological violence manifested in different ways such as jealousy and control, disguising itself as care. 
Some participants reported violence as reciprocal in their relationship:

I hit, swear, hit his face, then go home to cry. He does something, hits me, curses me and I return it too. I've even fainted at home, I was so upset. It was humiliation, but I can't keep control (P1/W-G1).

In two-way violence, physical, verbal and psychological aggressions were manifested.

\section{Passwords and Time: Motivators for Violence}

Among the elements cited by adolescents as stimulators of the phenomenon (namely: alcohol and drug use, lies, among others), social networks and the duration of the relationship were the most cited elements by adolescents.

Violence manifests itself via social networks through the insistence of a partner to want the password of the mobile phone and digital social networks like Instagram ${ }^{\oplus}$, Facebook ${ }^{\circledR}$, and WhatsApp ${ }^{\circledR}$, causing an invasion of privacy, manipulation and control over whom the other talks to. Not allowing this act is seen as distrust for those who want it. This may be observed in the following speeches:

I see her cell phone conversations every day, she can't have a password (...) (P6/M-G3).

You can control what he sees and does. I once deleted a lot of girls from his Facebook because I can't add male friends (P9/W-G3).

When someone doesn't give their password, I'm sure they are hiding something, there is no violence [insist] right $(\mathrm{E} 14 / \mathrm{H})$.

Thus, social networks are related to engendering new forms of violence and can be established in different dimensions, as in this report:

(...) I think he [my boyfriend] is more on my Facebook than his own (...) Sometimes he gets very stressed with what he sees, then he starts punching the wall (...) He scares me (G4-W).

There's a boy here from our school who beats his girlfriend because of Facebook, Whatsapp, these things, and the girl doesn't even let him like a photo, that leads to a fight for sure (P9/M-G4).

Several reports of participants expressed that the length of the relationship time was a factor conducive to violence, indicating that a longer relationship not only provides greater coexistence and intimacy, but also an wearing out of the relationship and loss of calmness by both. This may be observed in the speeches:

As [the] time passes together it tires you, wears on you, becomes stressful ... it end up in this (P3/M-G1).

In the beginning of dating there is no serious fighting, now in my case we have dated for over a year, I stay at his house, we spend a lot of time together, there is no way, we fight frequently, we more psychologically attack each other you know, we know how to manipulate each other (P11/W-G1).

My boyfriend said: 'I agree love, you're right'. But a year goes by, two, three, then he no longer agrees. Then he retorts. Then he begins the pinches, the pulls, on him, on both (P5/W-G4).
It was inferred that there was confusion between the notions of freedom, intimate relationship, and violent actions in many adolescent relationships over time. Moreover, the length of the relationship time was an element for the occurrence of two-way violence. In many reports, only after some time of relationship did one of the subjects of the relationship used physical and psychological aggression as a way to fight back against the violence suffered, as self-defense or as an alternative to end the violence they experienced.

\section{DISCUSSION}

Through the dialogical principle, a relationship and codependency between affection and aggression present in the intimate relationships of adolescents is observed. Conflicts and instabilities were faced by adolescents in two ways: first, through an association of violence with love, in which forms of violence are considered expressions of love or synonymous with love, especially through control over the partner and jealousy. These data confirm a study which reveals violent behaviors and jealous practices as accepted and associated with love in adolescents' intimate relationships ${ }^{(17)}$.

Given this, it can be considered that the dialogical affect-aggression was treated by adolescents as totally opposite and separate aspects, although their reports show that they were linked and solidified, but also hidden and in a process of invisibility. Concomitantly with this finding, difficulties in discerning between love practices such as kisses, and coercion to sexual practice were evidenced. Thus, a kiss does not fall into the category of sexual coercion for them.

The World Health Organization characterizes sexual violence as unwanted sexual acts or attempts using coercion, which include acts such as rape and harassment, which may be in the school or work environment, among others ${ }^{(18)}$. This phenomenon can be exerted by intimate partners within an informal relationship, in dating and marriages, and by strangers and in any context. In Brazil, according to the norms of Law No. 12.015/09, kissing and forcibly grabbing or pulling hair are considered sexual assaults and crimes against sexual dignity, and the person who commits such acts can be severely punished ${ }^{(19)}$.

Among all types of violence between intimate partners in Brazil, sexual violence has the lowest rate, which is due to a feeling of embarrassment by the person who suffers violence, precisely because it is perpetrated by an intimate partner and is associated with the issue of power. Given this, sexual violence between intimate partners suffers an invisibility process for the sake of taboo and the erroneous belief that it is only practiced by strangers ${ }^{(20)}$. Moreover, stigma and shame may contribute to omitting suffered violence, leading to underreporting of cases ${ }^{(18,20)}$. This is reinforced by the lack of knowledge regarding notification and its importance by adolescents and by the fragile technical training of health professionals, producing ignorance and uncertainties in their decision making and difficulty in identifying and visualizing the phenomenon ${ }^{(2,17)}$.

The second way for adolescents to deal with the instability of intimate relationships was to accept the violence, especially physical aggression perpetrated by females. This 
reveals a social stigmatization of girls by boys, a reproduction of machismo and misogyny by disqualifying the act performed by a woman, as if the practice were categorized as having less offensive potential by adolescents ${ }^{(17)}$. Disbelief of men being victims, as being dominated rather than dominant, presented in the statements that "men cannot be beaten by women", is a reproduction of an androcentric and ancient sexist discourse.

Men also suffer, albeit differently and to a lesser extent than women, the consequences and deprivations imposed by gender relations ${ }^{(17)}$. A study of Brazilian adolescents reinforces this conception and exposes the invisibility of violence against men because it is not considered by many to be gender violence ${ }^{(17)}$.

The statement by participant E11-M that when a man is beaten he does not go after his rights because there is no "José da Penha Law", makes explicit the lack of knowledge about Brazilian legislation which supports the safety and protection of any person, including males. Law No. 11.340/06, known as the Maria da Penha Law, is known to be specifically designed to curb and prevent domestic and family violence against women ${ }^{(21)}$. This law became well known in the country through the campaigns and initiatives of feminist movements, lawyers and the Brazilian government, but it was not disclosed with the same vehemence that men who suffer from domestic and family violence also has judicial protection for their safety, supported by the Brazilian Penal Code. Thus, a man must seek the police station and register a police report for the Penal Code to be applied.

Moreover, it is well known that the invisibility and taboo of man as a victim is the result of an androcentric view and social violence of gender relations. The latter establishes stereotyped roles which are socially constructed for men and women. Generalized and strict characteristics, values and standards are imposed, whether veiled or not, for different genders. With many recurring examples in society, these ideas that women are a fragile gender, cannot drive, and are divided between women to marry and those to enjoy are spread; while a man is strong and cannot cry because that is a "girly thing". Gender-based violence coupled with the myth of ideal love - which is also misrepresented in terms of power - enables and promotes violence between intimate partners in both heterosexual and homosexual relationships ${ }^{(17,22-23)}$.

In the principle of organizational recursion, it was possible to look at the interconnection that characterizes intimate partner violence. Intimate relationships based on the principles of jealousy and possession legitimized violence, justified unthinking actions, and exempted the perpetrator from liability. In addition, many forms of violence have become invisible, and both the perpetrator and the victim of the violence were often unaware of its manifestation and meaning in the relationship, or when aware, made it accepted and consented. In the participants' testimonies, the various meanings given to violence emerged as a normal and acceptable phenomenon, something that happens commonly in the relationships of intimacy among adolescents. These beliefs and the veiling of violence are characterized as the main factors in the perpetuation of the phenomenon.
In seeking to elaborate new meanings and break with reductionism, the principle of organizational recursion reveals that violent actions and experiences in relationships are products and producers of other experiences and behaviors. This aspect becomes clear in the bidirectionality evidenced in several national and international studies, in which both genders mutually assaulted each other and were assaulted ${ }^{(6,9,24-25)}$. However, even if there is a high percentage of two-way violence within an intimate relationship among adolescents, the damage and consequent harm from violence is greater, more severe, and longer lasting for women than men, whether physical, emotional, verbal, psychological or patrimonial ${ }^{(4-5,25)}$. In addition, there is a relevant number of women who claim to fight back against the violence suffered as a form of self-defense, which makes it possible to explain the high rates of violence of female authorship ${ }^{(25)}$.

One tried to obtain a broader view of the phenomenon through the holographic principle, but in different dimensions and with its particularities and connectivity. In this study, the interactions and connections of sexual, physical, verbal and psychological violence in the reports and experiences of adolescents are highlighted. The dimensions of verbal and psychological violence were the most frequent among participants, manifested in both the position of authors and victims, the latter being reinforced by different studies ${ }^{(6,17)}$.

The duration of the intimate relationship was revealed as a motivating element for the violence, showing that the longer the relationship, the greater the likelihood of the violence occurring. This finding confirms the results of recent studies ${ }^{(4,25-26)}$. A demonstration of loss of calmness and patience coupled with the tiredness generated by the insistence in monitoring digital social networks practiced by the partners were the main justifications for the physical and psychological violence which emerged throughout the relationship period in the present study.

The reports of adolescents and their interconnections through the holographic principle showed that digital technologies, especially smartphones and virtual social networks have paradoxically become factors for exposure to violence which were materialized by the insistence on obtaining access to passwords for phones and social networks as a means of gaining control over the partner; they may become obsessive and it may cause mood swings. Thus, in this context of virtual environments, new ways of reaching the partner's emotional state and self-confidence/self-esteem emerged, as well as other forms of IPV such as cyberviolence, demonstrated by receiving and sending videos and sexual photos without the consent of the partner.

The feeling of insecurity regarding the partner's relationship and attitude towards the mobilities, uncertainties, instability, uncontrollability of life events, associated with the element of relationship durability fostered control behaviors as strategies used by adolescents in their intimate relationships.

Thus, it is necessary to debate gender and sexuality relations in the spheres of education, safety and health to rethink traditional sex education. This is because many health and education professionals are unprepared and do not know or cannot take a direct approach to the phenomenon, judgments 
are made and disqualify the risk of more serious consequences $^{(27)}$. In addition, it is relevant to include the understanding of the relation of violence not only for women, but also for men as victims and not authors of violence in the curricula of basic education and health and education undergraduate courses, as this a problem surpasses the private environment, as well as the understanding of (social) gender violence. These aspects are essential for the visibility of the phenomenon, an effective sexual education and to promote healthy relationships. Therefore, it is understood that this study brings practical implications to the theme which can be transformed into actions with adolescents, considering the aspects addressed by them in this study and analyzed from the perspective of the Complex Paradigm.

While conducting this study, some difficulties occurred in data collection. The activities were carried out at the time of evaluations (October, November and December) and as combined with the school unit, the FGs and interviews took place during the participants' school period. Thus, with difficulties, there was an agreement regarding the evaluation dates, the availability of some teachers and the short time due to a delay by some teachers in dismissing the class participants.

\section{CONCLUSION}

The results indicated dialogical affection-jealousy/control present in relationships; organizational recursion of author-victim of violence; naturalization of violent acts which crosses gender, cultural and social issues; and technology as being preponderant for IPV among adolescents, denoting new forms of control and coercion. This deepening, contextualization and respect to the singularity of the participants was enabled by the use of the qualitative approach, especially considering that most quantitative productions are unveiled in the research theme, denoting important knowledge gaps in the qualitative approach of the phenomenon with such complexity.

In sum, the Complexity Paradigm has made an essential contribution to the search for developing a comprehensive view on the theme, providing greater clarity on the elements which make up the phenomenon, and especially on the interdependence and interconnectedness between them in an articulated and contextualized way. New studies addressing gender specificities and perspectives of other social actors, such as health and education professionals, are recommended.

\section{RESUMO}

Objetivo: Analisar as percepções de adolescentes sobre a violência nas relações de intimidade pela perspectiva do Paradigma da Complexidade. Método: Abordagem qualitativa, configurando-se como pesquisa social estratégica. Os participantes do estudo foram adolescentes entre 15 e 18 anos, frequentadores do ensino médio de duas escolas públicas de um município do interior do estado de São Paulo, Brasil. A coleta de dados foi realizada por meio do grupo focal e, como complementação, a entrevista semiestruturada. A análise dos dados foi fundamentada nos princípios dialógico, recurso organizacional e hologramático do Paradigma Complexo. Resultados: Participaram do estudo 39 adolescentes (14 do sexo masculino e 25 do sexo feminino). Por meio das categorias emergentes, percebeu-se que a violência na intimidade está atravessada pela dialógica afeto-ciúmes/controle, pela naturalização de atos violentos que permeia questões de gênero, culturais e sociais e pela tecnologia como preponderante para a violência de intimidade entre adolescentes, denotando novas formas de controle e coerção. Conclusão: $\mathrm{O}$ estudo traz aspectos presentes na violência na intimidade entre adolescentes, mostrando-os de forma articulada e interdependente. Tais aspectos se configuram em relevante contribuição para as ações de profissionais de saúde.

\section{DESCRITORES}

Adolescente; Violência por parceiro íntimo; Saúde do estudante; Pesquisa Qualitativa.

\section{RESUMEN}

Objetivo: Analizar las percepciones de adolescentes acerca de la violencia en las relaciones de intimidad desde el punto de vista del Paradigma de la Complejidad. Método: Abordaje cualitativo, configurándose como investigación social estratégica. Los participantes en el estudio fueron adolescentes entre 15 y 18 años, asistentes a la educación secundaria de dos escuelas públicas de un municipio del interior del estado de São Paulo, Brasil. La recolección de datos se llevó a cabo mediante el grupo focal y, como complementación, la entrevista semiestructurada. El análisis de datos se fundó en el principio dialógico, de recurso organizativo y hologramático del Paradigma Complejo. Resultados: Participaron en el estudio 39 adolescentes (14 del sexo masculino y 25 del sexo femenino). Según las categorías emergentes, se percibió que la violencia en la intimidad la cruzan la dialógica afecto-celos/control, la naturalización de actos violentos que está implicada en los temas de género, culturales y sociales y la tecnología como preponderante para la violencia de intimidad entre adolescentes, denotando nuevas formas de control y coerción. Conclusión: El estudio brinda aspectos presentes en la violencia en la intimidad entre adolescentes, mostrándolos de modo articulado e interdependiente. Dichos aspectos se configuran en relevante contribución para las acciones de los profesionales sanitarios.

\section{DESCRIPTORES}

Adolescente; Violencia de Pareja; Salud del estudiante; Investigación cualitativa.

\section{REFERENCES}

1. Organização Pan-Americana da Saúde; Brasil. Ministério da Saúde. Saúde e sexualidade de adolescentes: construindo equidade no SUS [Internet]. Brasília; 2017 [citado 2018 jul. 26]. Disponível em: http://bvsms.saude.gov.br/bvs/publicacoes/saude_sexualidade_adolescente_ construindo_equidade_sus.pdf

2. Oliveira RNG, Gessner R, Brancaglioni BC, Fonseca RMGS, Egry EY. Preventing violence by intimate partners in adolescence: an integrative review. Rev Esc Enferm USP. 2016;50(1):134-43. DOI: http://dx.doi.org/10.1590/50080-623420160000100018

3. Beserra MA, Leitão MNC, Fernandes MID, Scatena L, Vidinha TSS, Silva LMP, et al. Prevalência de violência no namoro entre adolescentes de escolas públicas de Recife/Pe -Brasil. Rev Enf Ref. 2015;4(7):91-9. 
4. Beserra MA, Leitão MNC, Fernandes MID, Scatena L, Vidinha TSS, Silva LMP, et al. Prevalence and characteristics of dating violence among school-aged adolescents in Portugal. Esc Anna Nery Rev Enferm. 2016;20(1):183-91. DOI: http://dx.doi.org/10.5935/1414-8145.20160024

5. Caridade S, Machado C. Violence in juvenile dating relationships: an overview of theory, research and practice. Psicologia (Lisboa). 2013;27(1):91-113.

6. Oliveira QBM, Assis SG, Njaine K, Pires TO. Namoro na adolescência no Brasil: circularidade da violência psicológica nos diferentes contextos relacionais. Ciênc Saúde Coletiva [Internet]. 2014 [citado 2018 jul. 26];19(3):707-18. Disponível em: http://www.scielo.br/ scielo.php?pid=S1413-81232014000300707\&script=sci_abstract\&tlng=pt

7. Carlos DM, Campeiz AB, Silva JL, Fernandes MID, Leitão MNC, Silva MAI, et al. Intervenções na escola para prevenção da violência nas relações de intimidade entre adolescentes: revisão integrativa da literatura. Rev Enf Ref [Internet]. 2017 [citado 2019 ago. 25] 14(4): 133-44. Disponível em: https://rr.esenfc.pt/rr/index.php?module=rr\&target=publicationDetails\&pesquisa=\&id_artigo=2712\&id_revista=24\&id_edicao=114

8. Foshee VA, Reyes HL, Gottfredson NC, Chanq LY, Ennett ST. A longitudinal examination of psychological, behavioral, academic, and relationship consequences of dating abuse victimization among a primarily rural sample of adolescents. J Adolesc Health. 2013;53(6):723-9. DOI: 10.1016/j.jadohealth.2013.06.016

9. Barreira AK, Lima MLC, Bigras M, Njaine K, Assis SG. Direcionalidade da violência física e psicológica no namoro entre adolescentes do Recife, Brasil. Rev Bras Epidemiol [Internet]. 2014 [citado 2018 jul. 26];17(1):217-28. Disponível em: http://www.scielo.br/scielo. php?pid=S1415-90X2014000100217\&script=sci_arttext\&tlng=pt

10. Morin E. O Método 5: a humanidade da humanidade. Porto Alegre: Sulinas; 2012.

11. Morin E. Ciência com consciência. 8ª ed. Rio de Janeiro: Bertrand Brasil; 2005.

12. Morin E. Introdução ao pensamento complexo. $3^{\mathrm{a}}$ ed. Porto Alegre: Sulina; 2007.

13. Instituto Brasileiro de Geografia e Estatística. Panorama Brasil-SP-Batatais. População [Internet]. Rio de Janeiro: IBGE; 2016 [citado 2018 mar. 20]. Disponível em: https://cidades.ibge.gov.br/brasil/sp/batatais/panorama

14. Minayo MCS, coordenadora. Pesquisa social: teoria, método e criatividade. 18a ed. Petrópolis: Vozes; 2001.

15. Glaser BG, Strauss AL. The discovery of grounded theory: strategies for qualitative research. New York: Aldine de Gruyter; 1997.

16. Pádua EMM. Complexidade e pesquisa qualitativa: aproximações. Série Acadêmica. 2015;32(2):39-48.

17. Cecchetto F, Oliveira Q, Njaine K, Minayo M C. Violências percebidas por homens adolescentes na interação afetivo-sexual em dez cidades brasileiras. Interface [Internet]. 2016 [citado 2016 ago. 18];20(59):853-64. Disponível em: http://www.scielo.br/scielo.php?pid=S1414$32832016000400853 \&$ script=sci_abstract\&tlng=pt

18. World Health Organization. Preventing intimate partner and sexual violence against women. Geneva; 2010.

19. Brasil. Lei n. 12.015, de 7 de agosto de 2009. Altera o Título VI da Parte Especial do Decreto-Lei no 2.848, de 7 de dezembro de 1940 Código Penal, e o art. 1oda Lei no 8.072, de 25 de julho de 1990, que dispõe sobre os crimes hediondos, nos termos do inciso XLIII do art. 50 da Constituição Federal e revoga a Lei no 2.252, de 1o de julho de 1954, que trata de corrupção de menores [Internet]. Brasília; 2009 [citado 2016 ago. 18]. Disponível em: http://www.planalto.gov.br/ccivil_03/_Ato2007-2010/2009/Lei/L12015.htm

20. Coelho EBS, Silva ACLG, Lindner SR. Violência por parceiro íntimo: definições e tipologias [Internet]. Florianópolis: Universidade Federal de Santa Catarina; 2018 [citado 2018 jul. 26]. Disponível em: https://www.unasus.gov.br/cursos/curso/45088

21. Brasil. Lei n. 11.340, de 7 de agosto de 2006. Cria mecanismos para coibir a violência doméstica e familiar contra a mulher, nos termos do $\S 80$ do art. 226 da Constituição Federal, da Convenção sobre a Eliminação de Todas as Formas de Discriminação contra as Mulheres e da Convenção Interamericana para Prevenir, Punir e Erradicar a Violência contra a Mulher; dispõe sobre a criação dos Juizados de Violência Doméstica e Familiar contra a Mulher; altera o Código de Processo Penal, o Código Penal e a Lei de Execução Penal; e dá outras providências [Internet]. Brasília; 2006 [citado 2016 ago. 2018]. Disponível em: http://www.planalto.gov.br/ccivil_03/_ato20042006/2006/lei/l11340.htm

22. Saffioti HIB. Gênero, patriarcado, violência. São Paulo: Fundação Perseu Abramo; 2004.

23. Scott J. Gênero: uma categoria útil de análise histórica. Educ Real [Internet]. 1995 [citado 2016 ago. 23];20(2):71-99. Disponível em: http://www.seer.ufrgs.br/index.php/educacaoerealidade/article/view/71721/40667

24. Flake TA, Barros C, Schraiber LB, Menezes PR. Violência por parceiro íntimo entre estudantes de duas universidades do Estado de São Paulo, Brasil. Rev Bras Epidemiol [Internet]. 2013 [citado 2016 jun. 10];16(4):801-16. Disponível em: http://www.scielo.br/pdf/rbepid/ v16n4/pt_1415-790X-rbepid-16-04-00801.pdf

25. Dardis CM, Dixon KJ, Edwards KM, Turchik JA. An examination of the factors related to dating violence perpetration among young men and women and associated theoretical explanations: a review of the literature. Trauma Violence Abuse. 2014;16(2):136-52. DOI: $10.1177 / 1524838013517559$

26. Barreira A, Lima M, Avanci J. Coocorrência de violência física e psicológica entre adolescentes namorados do recife, Brasil: prevalência e fatores associados. Ciênc Saúde Coletiva [Internet]. 2013 [citado 2018 mar. 20];18(1):233-43. Disponível em: https://www.scielosp.org/ article/ssm/content/raw/?resource_ssm_path=/media/assets/csc/v18n1/24.pdf

27. Apostólico MR, Hino P, Egry EY. Possibilities for addressing child abuse in systematized nursing consultations. Rev Esc Enferm USP [Internet]. 2013 [cited 2018 Apr 29];47(2):320-7. Available from: http://www.scielo.br/scielo.php?pid=s0080-62342013000200007\&script=sci_arttext\&tlng=en

Financial support:

The Coordenação de Aperfeiçoamento de Pessoal de Nível Superior (CAPES). Fundação de Amparo a Pesquisa do Estado de São Paulo (FAPESP - 2015/24069-5). 